\title{
Description Of Quality Learning Mathematics Of Students In Class Viewed From Emotional Intelligence In Class XI Transformation Materials In SMA 2 Majene
}

\author{
Djadir $^{1)}$, Hamzah $\mathrm{Upu}^{2}$, Hairunnisa Mahyuddin ${ }^{3)}$ \\ ${ }^{1,2,3}$ Mathematics Education Postgraduate Program \\ Universitas Negeri Makassar, Indonesia \\ E-mail: hairunnisa.mahyuddin@gmail.com
}

\begin{abstract}
Achievement of student learning outcomes and activities in learning is one of the things that can describe or is one of the benchmarks determining the quality of student learning. The emotional intelligence factor can affect the quality of learning. Therefore, the formulation of the problem in this study is how the description of the quality of mathematics learning of students is viewed from emotional intelligence on transformation material in SMA Negeri 2 Majene. The purpose of this study was to determine the description of the quality of mathematics learning of students in the classroom in terms of emotional intelligence on transformation material in SMA Negeri 2 Majene. This research is a type of qualitative research. The quality of student learning referred to in this study is the quality of student outcomes and activities. How to choose a subject that is by giving questionnaires to emotional intelligence to students then choose two students who have high emotional intelligence scores, two students with moderate emotional intelligence scores and two students with low emotional intelligence scores. The data collection method uses a combination of test, questionnaire and interview methods. Learning quality data obtained from quality test results and interviews of subject activities in the classroom. The results showed that the quality of the results of subjects with high emotional intelligence classified in the high and low categories, subjects with moderate emotional intelligence were both classified in the low category and subjects with low emotional intelligence classified in the medium and low categories, while for the quality of the process, the two subjects of emotional intelligence the first high and low emotional intelligence subject understands all indicators, whereas the second moderate emotional intelligence subject and the second low emotional intelligence subject do not meet all indicators.
\end{abstract}

Keywords: Emotional Inteligence; quality learning

\section{INTRODUCTION}

Education is a process in order to influence students to adjust themselves as best they can to their environment, thereby causing changes in themselves that allow it to function in people's lives. To deal with the development of increasingly sophisticated science and technology and increasingly intense globalization and the amount of competition in various matters that demand an increase in the quality of Human Resources (HR), it is necessary to increase the quality of human resources and achievement.

The success to improve the quality of graduates can be seen from the results of student learning which is the result of student learning processes that are influenced by many factors. We can find out and distinguish which factors can improve student learning. Many cases that cause study failure are caused by lack of ignorance what are the factors that can interfere with student learning. One of 
the most important factors is interest in learning. While interest in learning is influenced by internal factors and external factors.

Ishikawa (Raharjo, 2012) alludes to quality and defines quality as (a) quality and customer satisfaction are the same things and (b) quality is a broad concept that goes beyond just product quality to also include the quality of people, processes, and every other aspects of the organization. This means that quality has two dimensions, namely: (a) quality and customer satisfaction are the same thing, because if customers get the quality of goods or services, they will get satisfaction, (b) Quality is a broad concept that is not only product quality, but also the quality of people, work processes, and every aspect of the organization.

Mathematics is one of the subjects that is considered to be able to shape the quality of human resources for the better because mathematics that we know is logical and systematic. Therefore, it is necessary to improve the quality of education by taking into account the increase in student achievement. Success in the learning process will create good educational outcomes. High learning achievement as a benchmark for the success of quality or non-quality education.

In the learning process two-way communication occurs between the teacher and Purwanto students (2009). Without students the learning activities will not take place. Students must collaborate actively in realizing the stated goals, namely quality learning.

Learning activities are students' activities during the learning process, both physical and spiritual activities Ahmad Tafsir (2004). Without activities it can be said that students do not learn. Learning outcomes obtained by students will not be optimal. Without learning activities it will not give good results Nasution (2000). This is in line with the opinion of Sadirman (2011) who said that activity is a principle or principle that is very important in quality learning.

In the whole process of education in schools, learning activities are the main activities. This means the success or failure of the achievement of educational goals, much depends on how the process and learning outcomes experienced by students Tohirin (2005). in improving learning outcomes which will ultimately lead to an increase in the quality of Hamzah's education, Uno (2007). In achieving learning achievement there are various factors that influence it. As stated (Slameto, 2003) there are two factors that influence students' success in learning, namely: External factors (originating from outside the student) and internal (from students). External factors are factors originating from outside the individual such as family, school and community environment, while internal factors are three stages, namely fatigue (physical fatigue and spiritual fatigue), physical factors (health, disability) and psychological factors (intelligence, attention, interests, talents, motives, maturity, skills and readiness to learn).

The cause of the low achievement or learning outcomes of high school students today is certainly not inseparable from general factors. First, the factors within the students themselves are commonly referred to as internal factors with various forms and types. This factor is dominated by psychological conditions along with all the potential of students in the form of intelligence, including 
intelligence or intellectual intelligence which includes various abilities, such as reasoning, abstract thinking skills, and verbal abilities. Likewise other psychological factors such as self-concept and achievement motivation. Also emotional intelligence factors which include fortitude, social skills, empathy, patience, sincerity, tenacity, toughness, etc. Emotional intelligence relies on the relationship between feelings, character, and moral instincts which include selfcontrol, enthusiasm and perseverance, ability to adapt, ability to solve personal problems, control anger and the ability to motivate yourself. Especially in the learning process. In the learning process there is a change in the ability possessed by students in various fields, and the ability is obtained because of the learning effort. Children who master their emotions become more confident, optimistic, have enthusiasm and ideals, have the ability to adapt at the same time they will be better achievement in schools that are able to understand, as well as mastering existing problems. Second, namely factors originating from outside individual students, or often known as external factors. These factors also vary, for example environmental factors, both the family environment, as well as the school and community environment. In the school environment, teachers with various competencies are seen as one of the subfactors that contributes and contributes greatly to the success of students in the world of education (Daud, 2012).

Several studies relating to the relationship of learning quality with emotional intelligence come from research results (Thaib, 2013) explaining that the results of several studies at the University of Vermont regarding the analysis of the neurological structure of the human brain and behavioral research by LeDoux (1970) show that in important events in one's life , EQ always precedes rational intelligence. A good EQ can determine individual success in learning achievement to build career success, develop harmonious marital relationships and can reduce aggressiveness, especially among teenagers. According to Goleman, especially for people who purely have only high academic intelligence, they tend to have an unwarranted anxiety, are too critical, fussy, tend to withdraw, seem cold and tend to be difficult to express their frustration and anger appropriately. When supported by the low level of emotional intelligence, then people like this often become a source of problems. Because of the above characteristics, if someone has a high IQ but has a low level of emotional intelligence, they tend to be seen as stubborn, difficult to get along with, easily frustrated, not easy to trust others, are not sensitive to environmental conditions and tend to despair when experience stress. The opposite condition, experienced by people who have an average IQ level but have high emotional intelligence, so that we often find someone who is familiar with organizational life that involves a lot of emotional intelligence more successful.

Another explanation came from the researcher (Supardi, 2013) explained that the emotional intelligence of students is an important factor in improving the quality of student mathematics learning outcomes. Emotional intelligence (emotional quotient) is closely related to psychological dimensions such as: attention, interest, concentration, attitude, motivation, and other psychological conditions that need to be recognized and managed properly. Efforts to recognize and manage the psychological dimensions of students related to emotional 
intelligence need to be guided and fostered by teachers. Coaching efforts in the context of the introduction and management of the dimensions of emotional intelligence of students can be done through learning activities and providing innovative formative test form descriptions.

Emotional intelligence shows indicators of the level of students' ability to recognize and manage their emotional dimensions. Students who have High Emotional Intelligence will be able to recognize and manage their emotional dimensions well. Students who have good emotional intelligence tend to: be patient in facing various obstacles, persevering in learning, never give up, have high spirits, and are not easily satisfied in learning. Based on these phenomena, it is assumed that students who have good emotional intelligence will get good Mathematics learning outcomes.

Based on the background stated above, the writer raises the research problem with the title "Description of the quality of mathematics learning of students in terms of emotional intelligence" in class in terms of emotional intelligence?"

\section{RESEARCH METHOD}

This research is a qualitative research using descriptive method which aims to obtain a description of the quality of mathematics learning in students in the classroom in terms of emotional intelligence. This research was conducted at Majene 2 Public High School. Researchers choose the subject is purposive sampling. The subject of the research was class XI of SMA 2 Majene and the material tested was Geometry Transformation material. The number of subjects in this study were 6 students, based on emotional intelligence test scores, 6 students consisted of 2 students who had the highest scores, 2 students who had the lowest scores and 2 students who had scores around the average value. The instrument used was an emotional intelligence questionnaire, an essay-shaped test to determine the quality of student learning that includes learning outcomes, the instrument of student activity in the form of interview guidelines was made in such a way as to be able to find out more deeply about the description of the quality of student learning in mathematics which includes student learning processes ranging from physical activities to psychic activities in the observations conducted by researchers during $8 \mathrm{x}$ the meeting to further strengthen the research results. Data from the interviews were then analyzed qualitatively. Data analysis in research refers to the stages of qualitative data analysis according to Miles and Huberman in (Latif, 2015), namely collecting data, reducing data, presenting data, then finally drawing conclusions.

\section{RESULT AND DISCUSSION}

Description of the quality of student mathematics learning outcomes

Seeing the results of the whole subject learning outcomes test, it can be described that 3 out of 6 subjects can correctly answer question number one according to procedure 3, others make mistakes in calculation operations so that they are wrong in answering questions as well as the case in number two. For 
question number three about reflection only one subject answered incorrectly due to an error in the calculation operation, the same thing happened for question number four about rotation only one subject was incorrect in solving the problem, and for question number five all subjects answered correctly according procedure. So that the conclusion from questions number one to five is that all subjects actually understand how to solve problems about translation, reflection, rotation and dilation in simple form, but only a few subjects are not careful in their calculation operations. Questions number six to 10 are difficult questions about the composition of transformation, for question number six, four subjects answered correctly while the other two answered incorrectly, for number seven, three subjects answered correctly and three others chose not to work on number seven. , likewise with number eight, two subjects answered correctly while four of them chose not to do at all question number eight, then for question number nine there were no subjects who completed it correctly, and for number ten there were no subjects who answered correctly. The conclusion is that most subjects are still unable to solve the problem which is complicated in the transformation of the composition of the transformation.

Based on the value of the subject's learning test results, in terms of emotional intelligence, it was concluded that there were students with high emotional intelligence who got 86 learning outcomes with a high category and got the learning outcomes 55 with a low category, for students with moderate emotional intelligence there was a score of 48 and 44 are both classified in the low category, while students with low emotional intelligence one subject gets the value of learning outcomes 74 in the medium category and one other subject gets the value of learning outcomes that is 42 in the low category.

Description of the Quality of Student Activities in the Classroom

Data on students' mathematics learning activities in the classroom, obtained from a questionnaire through interviews and direct observation from researchers during class $8 \mathrm{x}$ meetings to further explore information from students.

The three subjects namely KES1, KES2 and KER2 do not meet the second indicator which is understanding the material, all three subjects have the same problem that is understanding, paying attention and listening to the teacher explain a material only in certain circumstances, and will carry out other activities that can interfere with learning, as is the case in KES1, KES2 and KER3 will tell stories with their classmates if they are not paying attention to the teacher explaining the material.

As many as two subjects who did not meet the third indicator, KES2 and KER2, for the case experienced by KES2, the subject claimed to be picky about the teacher if he wanted to ask questions and would not dare to express an opinion when asked, whereas for the KER2 subject it was only not brave in expressing opinions.

There is only one subject that does not meet the fourth indicator, the subject KES2, the subject claims he more often borrowed his friend's notes to copy than to record directly the material taught by his teacher when learning takes place. 
All three subjects did not meet the fifth indicator. All subjects KES1, KES2 and KER2 admitted that during the test, they often cheated, KES1 and KES2 did the individual assignment given by the teacher with their friends, while KER2 would work on the tasks that he understood.

From these three subjects, it was concluded that KES1 did not meet two indicators, namely the second indicator about understanding / paying attention to the teacher explaining and the fifth indicator about doing the assignment, while KES2 did not meet the indicators as many as four indicators namely the second indicator about understanding and paying attention to the teacher explaining, the third indicator about providing opinions, the fourth indicator is about recording the lesson, and the fifth indicator is about doing the assignment, and the subject of KER2 does not fulfill as many as three indicators namely the second indicator about understanding and paying attention to the teacher explaining, the third indicator about expressing opinions, and the fifth indicator about doing the assignment.

\section{Discussion}

Seeing from the results of the study, researchers found other findings that are not in line with the theory, reviewing one of the quotations in the previous chapter that was explained by Winkle (Kartini, Cristina 2008) that good and bad quality of learning of a student depends on the results achieved by these students in the learning process.

In fact, there are subjects with the same emotional intelligence category but have different quality results, then related to student learning activities in the classroom, such as the results of the interviews of subjects KET1 and KET2 which clearly show the difference between KET1 in the high category and KET2 KET2 in the low category, according the results of interviews are classified as active students that always pay attention to the teacher when teaching, when asked to express opinions always with pleasure and confidence to express their opinions, while the subject KET2 pay attention to the teacher according to circumstances if it is not fun then the subject KET2 will ignore the teacher's explanation. in fact most of the subjects are less active in class when learning takes place. Things like this that can greatly affect the quality of student outcomes, according to Djamarah (2010), active learning is needed by students to get maximum learning outcomes, when students are passive or only receive information from the teacher, there will be a tendency to quickly forgets what has been given by the teacher, and according to Sadirman (2011), Students can be said to be active if the student participates in learning activities such as engaging in group discussions and using their abilities in completing their assignments and when the theory is. In line with the theories of Djamarah and Sadirman, Mulyasa (Rochyati \& Ratna, 2003) also explained the same thing as the quality of a student's learning in terms of the process and results, for the terms of the process of learning a qualified student when students are actively involved in the learning process.

Even this can be a result of the low quality of student learning outcomes even though their emotional intelligence is in the high or medium category. The 
activeness of asking students in the learning process will cause interactions between the teacher and students, this activity will affect learning outcomes because students 'insights and knowledge grow in tandem with the students' curiosity Johnson (2002).

The next case based on the results of observations by researchers is the subjects KES1, KES2 and KER1, especially for subjects KER1 and KER2 with the same category of emotional intelligence is very much different, each KER1 subject is given a definite task to complete itself while for the KER2 subject sangta less in terms of trying alone in working on assignments given by the teacher. Often these three subjects when given the task of just copying the work of their friends without trying first. Then the explanation of Postman and Weeingartner (1969) explains that as students whose quality of learning is good is shown by perseverance, perseverance, discipline, innovation power, creativity and responsibility and these three subjects do not show persistence, confidence, innovation and responsibility.

The problem about KES2 considers mathematics to be a difficult subject in the results of the interview, subject KER1, KES1 also explained that it prefers other subjects to mathematics even though the results of the test of learning quality are pretty good, this also occurs because it allows the subject to have good quality learning in other subjects. for mathematics, or it can be said that the subject's interest in mathematics is lacking, things like this greatly affect differences in the results of the quality of each subject even though in the same category of emotional intelligence.

It is also interesting for the researchers to discuss, on the comparison of subjects KET1 and KET2 who have high emotional intelligence categories but get different learning quality shown in indicators of learning activities in the classroom asking or answering questions, the KET1 subjects will ask directly to their teacher when they don't understand the material which is explained, whereas on the subject KET2 will ask depending on circumstances as he will ask depending on the teacher.

In the background clearly explained that affect the quality of student learning not only from the students themselves but also from students Slamento (2003), then related to that explained Purwanto (2009) in the learning process for a good quality of communication occurs two the direction between teacher and student, teacher and student must collaborate actively in realizing the aim of a learning in order to be quality. The teacher is also here as one of the main roles in student learning activities to become quality learning in the classroom.

Then viewed in terms of emotional emotional subject, the subject of the same category of emotional intelligence has a different quality of learning outcomes. This can be seen from the observation that there are students who seem relaxed in doing the given task, then based on the results of the interview, some subjects such as KER1 and KER2, compared to KER1, KER2 subjects tend to be reluctant to ask questions about problems they do not understand. So this has an impact on the acquisition of low learning outcomes.

The theory explained in the previous chapter that students who have high emotional intelligence have good learning outcomes and conversely students who 
have low emotional intelligence will have low learning outcomes. Dawson (Triatna \& Risma, 2008) explains that individuals who have a better level of emotional intelligence can be skilled in calming themselves quickly, more skilled in focusing attention, better in dealing with others, and for academic work at school better, supported also research from Walter Mischel (Goleman, 1998) on marshmallow challange at Stanford University which shows that children who are able to push their hearts from childhood when there is a high school level (SMA) are academically more competent, more capable of compiling ideas logically, and have a high passion for learning. They had significantly higher scores than children who were unable to postpone their impulses.

There are several explanations for why this happens because students who have high levels of emotional ability to manage tend to be smart to handle, manage, and balance their emotions.

Based on observations, it can be seen that some students actively pay attention if their friends call to ask answers, so that they will be easily dispersed in solving problems. According to Hurlock (Pujianti, 2012), empathy is the ability to put oneself in another person's psychological state and to see a situation from another person's point of view. Someone who is empathetic according to Pujianti (2012) is described as someone who is tolerant and friendly. This empathy according to Batson will encourage someone to do help (Pujianti, 2012). However, students need to understand when is a good time to help and when not. They will write the answers given by their friends, no matter right or wrong. This can be seen from some of the same incorrect answers made by some students from the learning achievement test given. So in this case, the higher the empathy feeling, the lower the learning outcomes they get.

Conversely, students who have fairly high learning outcomes in the sense of a moderate category, namely the subject KER2, look like to be alone and lack empathy for their surroundings. Students like this look accustomed to doing or trying on their own. So they will focus on solving the given problem. Students who have high learning outcomes also tend to lack aspects of managing emotions when compared to some students who have low learning outcomes. Their lack of skill in managing emotions makes them more likely to experience frustration if there is a task or problem that they cannot solve. However, sometimes a person's success in learning can start from frustration.

According to Steven and Howard (2002), emotional intelligence is not a talent and achievement related to a person's ability to succeed in a particular skill or activity or discipline. So emotional intelligence does not affect the ability of students to obtain high scores for mathematics learning outcomes.

Steven and Howard further explained that intelligence measures the speed of a person to learn new things, focus on various tasks and exercises, store and recall objective information, engage in thought processes, work with numbers, abstract and analytical thinking, and solve the problem is by applying pre-existing knowledge that is part of intellectual intelligence. So that the success of learning mathematics will be more dominated by the intellectual level of students. 
Furthermore, the results of research conducted by O'Connor and Little (Shipley et al, 2011) who conducted research on the relationship between emotional intelligence and learning outcomes in some students showed that regardless of the type of instrument used to measure it, emotional intelligence is not a predictor strong for learning outcomes. A similar study was also carried out by Bastian, Burns, and Nettelbeck (Shipley et al, 2011) to 246 third semester students in the first year at one of the universities in Australia with the results of research showing that there was no statistically significant relationship between emotional intelligence and learning outcomes.

Furthermore, Karen Arnold (Fauziah, 2014) emphasized that practical academic intelligence, such as learning outcomes, does not offer preparation to deal with the turmoil caused by life's difficulties. However, one's emotional intelligence has a major influence on the fate of one's life. So it can be concluded that student learning outcomes, especially in mathematics are not influenced by emotional intelligence, but emotional intelligence will have an influence on students' future success. Goleman added that the balance between intellectual intelligence and emotional intelligence is the key to successful learning of students in school. So emotional intelligence is very important to be considered and developed.

\section{CONCLUSION AND SUGGESTION}

Based on the results of the research with the discussion, the conclusions obtained from this study are as follows: (1) The quality of student learning outcomes with the results obtained scores included in the high category, while subjects with high emotional intelligence second are included in the low category. Subjects with the first and second moderate emotional intelligence, both included in the low category, and for subjects with low emotional intelligence first included in the medium category, and subjects with low emotional intelligence second included in the low category. Subjects with the same emotional intelligence but belong to different categories of results, this is possible due to various factors, and student learning outcomes, especially in mathematics are not influenced by emotional intelligence. (2) The quality of students' mathematics learning in class, three of the six subjects meet all indicators, namely the subject with the highest highest emotional intelligence and the second highest, and the subject with the lowest emotional intelligence first, then for subjects who do not meet several indicators are subjects with emotional intelligence the first and the second, also subjects with low emotional intelligence second.

\section{REFFERENCES}

Abdurrahman, M. (2003). Pendidikan bagi anak berkesulitan belajar. Jakarta: PT Rineka Cipta.

Aritonan, K. T. (2008). Minat dan Motivasi dalam Meningkatkan Hasil Belajar Siswa, 11.

Daud, F. (2012). Pengaruh Kecerdasan Emosional (EQ) dan Motivasi Belajar terhadap Hasil Belajar Biologi Siswa SMA 3 Negeri Kota Palopo. Jurnal Pendidikan Dan Pembelajaran (JPP), 19(2), 243-255. 
Djamarah, Syaiful Bahri. (2010). Guru dan Anak Didik dalam Interaksi Edukatif. Jakarta: Rineka Cipta.

Fauziyah, A. (2013). Pengaruh Kreativitas dan Kecerdasan Emosional Siswa terhadap Hasil Belajar Matematika pada Materi Garis Singgung Lingkaran pada Siswa Kelas VIII MTsN Karangrejo Tulungagung Tahun Ajaran 2013/2014. Skripsi. IAIN Tulungagung.

Gie, T. L. (1998). Cara Belajar yang Efisien. Yogyakarta: PUBIB.

Ginanjar, A. (2007). Rahasia Sukses Membangun Kecerdasan Emosi dan Spiritual: ESQ. Jakarta: Arga.

Goleman, D. (1998). Working with emotional intelligence. Bantam.

Goleman, D. (2000). Kecerdasan Emosional. Gramedia Pustaka Utama.

Gusniwati, M. (2015). Pengaruh Kecerdasan Emosional Dan Minat Belajar Terhadap Penguasaan Konsep Matematika Siswa Sman Di Kecamatan Kebon Jeruk, 16.

Hakim, T. (2005). Belajar secara efektif. Niaga Swadaya.

Hamzah \& Muhlisrarini. (2014). Perencanaan dan Strategi Pembelajaran Matematika. Jakarta: RajaGrafindo Persada.

Hamzah, Uno. (2007). Model Pembelajaran Menciptakan Proses belajar Mengajar yang Kreatif dan Efektif. Jakarta: PT Bumi Aksara

Hutabarat, E. P. (1995). Cara Belajar Pedoman Praktis Untuk Belajar Secara Efisien dan Efektif Pegangan Bagi Siapa Saja Yang Belajar di Perguruan Tinggi. Jakarta: PT. BPK Gunung Mulia.

Johnson, Elaine B. 2002. Contextual Teaching and Learning. California: Corwin Press inc.

Kartnini, Cristiana. (2008). Peningkatan Pembelajaran Minat Matematika.

Latif, S. (2015). Deskripsi kemampuan koneksi matematis dalam menyelesaikan masalah matematikasiswa yang berkemampuan awal tinggi di kelas VII SMP 24 Bulukumba.tesis. Universitas Negeri Makassar, Makassar.

Masykur, M., \& Fathani, A. H. (2007). Mathematical Intelligence Cara Cerdas Melatih Otak dan Menanggulangi Kesulitan Belajar. Jogjakarta: Ar-Ruzz Media.

Nasution. (2000). Didaktik Asas-Asas Mengajar. Jakarta: Bumi Aksara.

Nurhayati, E. (2014). Psikologi Pendidikan Inovatif. Yogyakara: Pustaka Pelajar.

Nyayu, K. (2014). Psikologi Pendidikan. Jakarta: Pt. Raja Grafindo Persada.

Pujianti, A. (2012). Kontribusi Empati terhadap Perilaku Altruisme pada Siswa Siswi SMA Negeri 1 Setu Bekasi. Skripsi. Universitas Gunadarma.

Purwanto. (2009). Evaluasi Hasil Belajar. Yokyakarta: Pustaka Pelajar.

Raharjo, S. B. (2012). Evaluasi Trend Kualitas Pendidikan Di Indonesia. Jurnal Penelitian Dan Evaluasi Pendidikan, 16(2), 511-532.

Rochyati, Umi \& Ratna. (2011). Jurnal Peningkatan Kualitas pembelajaran dan Character Building.

Saputra, Kadek Yudi. (2015). Pengaruh Proses Pembelajaran Motivasi Belajar Terhadap hasil Belajar IPS Siswa SMP Maulana Pengayaman. Vol.5 Nomor 1. 
Sardiman, A.M. (2011). Interaksi dan Motivasi Belajar Mengajar. Jakarta: Raja Grafindo Persada.

Satria, D. (2010a). Korelasi Aktivitas Belajar di Luar Jam Sekolah dengan Hasil Belajar Fiqih Siswa di Madrasah Aliyah Pondok Pesantren Darussalam Saran Kabun Kecamatan Kabun Kabupaten Rokan Hulu.Tesis. Universitas Islam Negeri Sultan Syarif Kasim Riau.

Satria, D. (2010b). Korelasi Aktivitas Belajar Di Luar Jam Sekolah Dengan Hasil Belajar Fiqih Siswa Di Madrasah Aliyah Pondok Pesantren Darussalam Saran Kabun Kecamatan Kabun Kabupaten Rokan Hulu, 73.

Shapiro, L. E. (1998). Mengajarkan emotional intelligence pada anak. Jakarta: Gramedia.

Shipley, N. L., Jackson, M. J., Segrest, S. L. (2011). The Effects of Emotional Intelligence, Age, Work Experience, and Academic Performance. Research in Higher Education Journal. University of South Florida St. Petersburg.

Slameto. (2003). Belajar dan Faktor-faktor yang Mempengaruhinya. Jakarta: PT. Rineka Cipta.

Slameto. (2010). Belajar dan Faktor-Faktor yang mempengaruhinya.

Steven, S. J, \& Book, H. E. (2002). Excecutive EQ. Bandung: Penerbit Kaifa

Sugiyono. (2014). Metode Penelitian kombinasi (mixed methods). Bandung: Alfabeta.

Suhendri, H. (2011). Pengaruh Kecerdasan Matematis-Logis Dan Kemandirian Belajar Terhadap Hasil Belajar Matematika, 11.

Supardi, US. (2008). Pengaruh Bentuk Tes Formatif dan Kecerdasan Emosional terhadap Hasil Belajar matematika. Jurnal Ilmiah FAKTOR Exacta

Susilawati. (2012). Program Bimbingan dan Konseling untuk Mengembangkan Kecerdasan Emosional Siswa SMP. Skripsi. Universitas Pendidikan Indonesia.

Tahir, S. R. (2015). Profil berfikir kritis dalam pemecahan masalah matematika ditinjau dari perbedaangender kelas XI SMA negeri 1 Tondong Tallasa.Tesis. Program Pasca Sarjana Universitas Negeri Makassar, Makassar.

Tafsir, Ahmad. (2004). Psikologi Pembelajaran Pendidikan Agama Islam. Jakarta: PT. Raja Grafindo Persada

Thaib, Eva Nauli. (2013). Hubungan Prestasi Belajar dengan Kecerdasan Emosional. Jurnal Ilmiah, Vol.XIII No.2.

Tiro, Muhammad Arif. 2010. Cara Efektif Belajar Matematika. Makassar: Andira Publisher.

Tohirin. (2005). Psikologi Pembelajaran Pendidikan Agama Islam. Jakarta : PT. Raja Grafindo Persada

Triatna, C., \& Risma, K. (2008). EQ Power Panduan Meningkatkan Kecerdasan Emosional. Bandung: Citra Praya.

US, S. (2013). Hasil belajar matematika siswa ditinjau dari interaksi tes formatif uraian dan kecerdasan emosional.

Zulkarnain, Z. (2017). Deskripsi Kualitas Belajar Matematika Siswa Ditinjau dari Domisili dan Perbedaan Gender pada MTs Muhammadiyah Punnia 